\title{
WEED CONTROL - UNDERSTORY WEED MANAGEMENT IN COCONUT LANDS
}

\author{
by \\ L. V. K. LIYANAGE and M. DE. S. LIYANAGE ${ }^{1}$
}

\section{INTRODUCTION}

Coconut (Cocos nucifera L.) is by far the most extensively cultivated plantation crop in Sri Lanka. It is essentially a small holder crop comprising about $86 \%$ of small. holdings and homesteads and the balance belonging to the estate sector. The growth habit of the palm and its canopy structure requires a wide, spacing between palms, which permits abundant sunlight to the understory. As a result, the unutilised space beneath the plantation becomes invaded by a wide range of perennial and annual weed species. Such weeds invariably compete with coconut for soil moisture and nutrients, affecting its growth and yield and obstructing routine estate practices. Management of the understory weed growth is, therefore, considered an essential step in maintaining the plantation. In fact, the cost of weeding accounts for a substantial proportion of the total recurrent expenditure for maintenance.

The density and vigour of weeds and their distribution depend largely on the age of plantation, agro ecological zone and size of holding. Generally, the microclimate of the understory in young coconut stands is more favourable for rapid growth of noxious weed species than in mature plantations. Further, weed competition appears to be more serious in the Dry Zone than in the Wet Zone. In the estate sector where palms are systematically planted and maintained as a monoculture, weed growth is more serious than in small holdings. In contrast, small holdings usually maintain a high density of palms, somewhat irregularly planted and carry some form of disorganised mixed cropping along with other trees. Due to the shady conclitions of the understory, weed growth is much less in small holdings.

Due to fluctuating farm-gate prices of coconut and low income generating ability, the majority of coconut growers tend to neglect their plantations, allowing the understory to become invaded by weeds.

In the past very little effort has been made to advice coconut growers on the problems of understory weed management. It is therefore pertinent to discuss the occurrence of major weeds in coconut lands and their management, in order to create an awareness among coconut growers of the benefit of understory weed control for better management of coconut plantations.

\section{OCCURRENCE OF WEEDS IN NEW/REPLANTATIONS AND YOUNG PLANTATIONS}

Coconut seedlings in newly established and replanted fields and young palms suffer most from weed infestation. The degree of weed competition is more intense in this situation due to the availability of abundant sunlight and other resources. In Trinidad, Kasasian and Seeyave (1969) reported a 64 peicent reduction in growth of coconut seedlings in unweeded plots. Understory weed management is therefore very critical during the seedlings and early stage of palm growth, say up to five years. A good knowledge of the type of weed species occurring in this situation, their identification and growth habit will be of immense help to the gorwers.

Among the range of perennial grass weeds found in newly establis hed and young plantations, illuk (Imperate cylindrica) is undoubtedly the most noxious and troublesome weed. It is more widespread in the Intermediate and Dry Zone of the coconut areas, particularly in sandy soil. The ability of illuk to thrive well on marginal lands and its spread to new areas poses a serious problem to coconut growers. It grows to a height of $60-90 \mathrm{~cm}$ producing a deeply penetrating

\footnotetext{
${ }^{1}$ Coconut Research Institute Lunuwila, Sri Lanka
} 
underground rhizome with a compact silvery-white inflorescence (Plate 1). Fox-tail grass or Managrass (Pennisetum Polystachyon) is another perennial weed abundant in newly established and young plantation, causing serious problems to the growers. It grows luxuriantly in the Wet and Intermediate Zone, particularly in Puttalam, Kurunegala and GanTpaha districts and predominant in lateritic gravel or clay loam soils. It grows to a height of 1.8-2.4 m and produces yellowish-green hairy inflorescene resembling that of a fox-tail with deeply penetrating undergraund rhizomes.

Aristida setacea (Ath-thuththiri), Panicum repens (Atora or Couch grass), Cynodon dactylon (Kukul atawara), Cenchrus echinatus (Kuweni) are the other common, but relatively less troublesome weeds that invade the understory of young plantations. Aristida is a dominant weed in the Dry Intermediate and Dry Zones, particularly abundant in Narammala, Kuliyapitiya and Mundel areas. Both couch grass, cynadon produce extensive underground rhizomes and are widely distributed in sandy tracts of the Intermediate and Dry Zone. Cenchrus, is-common in Bingiriya and Chilaw areas which easily clings on to clothes and footware.

Among shrubs, Chromolaena odorata or Podisinghomaran (Syn.Eupatorium odoratum) is the most troublesome weed that dominates the understory of young plantation. It is widespread in Galle, Kalutara, Gampaha, Kurunegala and Chilaw districts with a remarkable ability to thrive on gravel soils in the dry zone. It grows to a height of about 1.5-1.8 $\mathrm{m}$ and yellowish stem, dark green leaves with serrated marging, bearing a cluster of powdery-blue florets at the top. The mature leaves give off a pungent odour when crushed (Plate 2).

Among herbaceous weeds, Mikania scandens (Wathupalu) thrives well particularly in the wet and intermediate zones. It is a creeper producing arrow-head like or heart shaped leaves with white flowers borne on cluster. Being a perennial creeper, it is sometimes maintained as a ground cover, especially in dry areas. However, if its growth is unchecked, it can cause serious problems as it climbs on to coconut seedlings and smothers the entire canopy, thus preventing sunlight reaching the fronds and limiting the spread of canopy. Tephrosia purpurea (Pila), Acanthespermum hispidium (Nerenchi), Ocimum sanctum (Madurutala) arc the other herbaceous weeds that occupy the understory cover in new plantations and young plantation particularly in the Intermediate and Dry Zones. These weeds appear to be more widespread in sandy tracts of Puttalam, Madampe, Mundel, Kuliyapitiya, Chilaw, Nikaweratiya and Wariapola areas. Pila, is a leguminous plant which grows to about $60 \mathrm{~cm}$ high with spreading branches and producing purple-white flowers. Nerenchi, is a surface ramifying species. Madurutala grows to $45-60 \mathrm{~cm}$ high and produce flowers along the stem whose leaves have a repulsive smell when crushed.

\section{MAJOR WEEDS IN MATURE PLANTATIONS}

In mature plantations where the understory is exposed to varying levels of shade, broad-leaved and annual herbaceous weeds are ryfore common than perennial grasses due to their ability to tolerate shady conditions. Even when perennial grass weeds do occur, they are generally less aggressive and less troublesome to the coconut growers. It has been observed that during the early mature phase of the palm stand, say around 10 - 20 years, presence of weeds may not pose a serious problem due to heavy shading of the understory by the well developed coconut canopy. However, from 20 years and above, sufficient light filters in to the understory to allow weed growth again. Although, the degree of competition due to weed growth is less intense in mature stands, there are reports showing a 14 percent reduction in copra yield of palms in unweeded plots (Martin and Mudaliar 1983). In addtion, heavy weed infestation of the understory in mature plantation. obstructs routine estate practices such as picking and collecting of nuts, movement of tractor and carts during the pick, resulting in a 6onsiderable loss of coconuts.

Among perennial grasses, illuk, Fox-tail grass and Cyperus rotundus (Kalanduru) form the most common weed flora in mature plantations. Among these, Cyperus is more shade tolerant and 
especially widespread in the Wet and Wet-intermediate zone, particularly in gravelly soils. It can be easily identified by the triangular stem with purplish flower heads. It multiplies rapidly from underground black iffegular shaped rhizomes, which can survive in the soil for longer periods. In mature plantations, illuk and fox-tail grass usually occur in patches where relatively more sunlight penetrates the understory, say bordering roads and vacant spaces or in ne\&cted plantations due for replanting. Among shrubs, Chromolaena and Lantana camera (Gandapana) are the common weeds found in this situation. Both these species are well adapted to a range of climatic regions and soil types and occur in gravelly and sandy soils in the wet and dry regions. Of these, Lantana is a shade tolerant fast spreading woody shrub reaching a height of 1.8-3.6 m and easily identified by the pinkish or purple round flowtr heads with yellow centres. Chromolaena can only tolerate partial shade and therefore, its growth is restricted in this situation.

Among herbaceous weeds, Sida species (Sida acuta, S. rombifolia, S. cordifolia) Mimosa Pudica, Ageratum conyzoides, Cassia species (Cassia tora, Ca. occidentalis) Euphorbia hirta (Wairubber) usually dominate the understory of mature coconut stands, as these species arc relatively shade tolerant. Of these, Sida and Mimosa are widely distributed in the Wet and Itermediate Zone, particularly in gravelly soils. Sida acuta is a low-growing, usually twiggy perennial with small lance-shaped leaves. Mimosa is a leguminous prostrate perennial herb, 15-20 cm tall, particularly widespread in gravelly soils of the Wet and Intermediate Zone. It has a pinkish, round flower head, thorny stems with small leaves sensitive to touch and hence the name sensitive plant. Due to its thorny nature, it poses a serious problem during picking and collecting of nuts. Ageratum is another shade tolerant thorny herbaceous annual weed with terminal or axillary flower heads. Cassia tora is another herbaceous weed widespread in the wet and Wet intermediate zone especially in Gampaha, Mirigama, Divulapitiya, Giriulla and Narammala areas. It has a deep tap root and can be readily recognised by its bright-yellow flowers and sickle-shaped pods. Leaves when crush-ed give off a fowl odour. Euphorbia, Mikania and Pila are some of the other common but less troublesome herbaceous weeds found in mature plantations. In the Intermediate and Dry Zone, Mikania is usually maintained as a ground cover particularly in sandy soil where leguminous cover crops are somewhat difficult to establish.

\section{WEED MANAGEMENT IN COCONUT PLANTATIONS}

Being a perennial crop, complete eradication of the understory weed cover in coconut is not necessary, excepting perhaps the most troublesome and pernicious types. In any case, clean weeding should not be practised as it is a costly and labour intensive operation. Further, clean weeding particularly in wet areas can lead to soil erosion. Therefore, in most situations, control measures should be aimed at suppressing or managing weed growth to, a level that they would not compete with coconut, particularly for soil moisture and nutrients. As the available space in coconut monoculture is hardly being used, weed control has become a routine practice in estates and medium-size coconut holdings, which is done at considerable expense.

Weeds in coconut lands may be controlled by different methods under the broad categories of Mechanical, Cultural and Chernical mcthods. But, an integrated approach involving a combination of several methods Would appear to be more efficient and econornical in the control of troublesome perennial species. In the present context of high labour wages and scarcity of labour, the traditional method of controlling weeds with underground rhizomes by manual cligging has become virtually impossible. As weed competition is likely to be more intense in the Intermediate and Dry Zone, growers in these areas have, to be more cautious about taking prompt control measures against weeds than those in the Wet Zone.

Tle choice of a particular method for systernatic management of weeds largely depend on the age of coconut stand, type of weed and its distribution, and on the size of holding. 


\section{WEED MANAGEMENT IN NEW/YOUNG PLANTATIONS}

As coconut seedlings and young palms are known to be very sensitive to weed competition, weed management to suppress under§tory growth is very important at this stage.

\section{Integrated Method}

Of all major weeds occupying the understory of new/young plantation, illuk is the most difficult weed species to bring under control. In the past, many gorwers especially in dry areas have grappled with illuk control and so far very little success has been achieved, mainly as a result of not using a proper method. Ifluk being a sun-loving plant, becomes more aggressive in new and young plantations than in mature plantations, which makes it difficult achieve complete control. in a short period. If the plantation is heavily infested with illuk, the most effective, and economical method is to follow an integrated method which involves the removal of aerial parts and herbicidal. (weed killers) application followed by the establishment of leguminous creeping cover like Pueraria phaseoloides (Puero) or Calopogonium mucunoides (Calopo). The aerial parts may be cut down either with a slashing knife, band operated. brush cutter or with a tractor drawn rotary slasher followed by the application of a systernic or translocated herbicide like Glyphosate (Roundup) at 3.3 $\mathrm{Kg}$ a.i./ha on the new flush of leaves that emerge 2 - 3 weeks after slashing, to allow penetration of chernical into under ground rhizomes. The cover crop may be established two weeks later by broadcasting pre-treated seeds at the rate of $8-10 \mathrm{~kg} / \mathrm{ha}$. Leguminous ground covers, apart from being a "smother crop", improve soil fertility and retain soil moisture, which is particularly important in dry areas. In the Philippines, Abad and San Juan (1980) reported that heavy infestation of illuk in a two-year old coconut grove was completely controlled over a period of $4-7$ months with a ground cover of 'Calopo' established through over-seeding ( $25 \mathrm{~kg} / \mathrm{ha}) 15$ days after spraying of Roundup at the rate of $3.1 \mathrm{~kg} / \mathrm{ha}$. Subsequently, it has been confirmed that 'Roundup' at this concentration did not produce any phytotixicity on coconut seedlings (Juan, et al, undated). In Sri Lanka, spraying of 'Roundup' at 21 in 3801 of water/ha (2\% solution) on young foliage that emerge after slashing has given excellent control of illuk in a young plantation in the dry zone (Liyanage, unpublished). An equally effective method of illuk control in young plantations in clay-loamy soil is to use Dalapon (Basfapon) at $10 \mathrm{~kg} / \mathrm{ha}$ in combination with a surfactant (Teepol) at $1.4 \mathrm{l} / \mathrm{ha}$ to allow better penctration of the chernical as an initial spray and repeat at 4 weeks. In smallholdings, perennial cultivars of winged bean (eg. SLS 40, SLS 42) may be planted in rows in place of cover crops. In this situation, the initial weed growth may be suppressed until about 3 - 4 months either by manual weeding or application of a pre-emergence herbicide like Diuron between rows at $3 \mathrm{~kg} / \mathrm{ha}$. The integrated weed management described above could be applicable to other troublesome weeds like Fox-tail grass, Couch grass and Chromolaena. In well managed plantations where weed growth is not so widespread, traditional practice is to remove tall weeds between rows before flowering and ring weed around the palm to a distance of $1.5 \mathrm{~m}$ just before manuring, followed by mulching with $1-2$ layers of coconut husk or weed trash. Mulching with coconut fronds especially in clayey or sandy soil is not recommended for the reason that it can attract termites which can cause considerable damage to seedlings. During peak labour use, ring weeding can be replaced by spot application of a herbicide. It has been shown that Paraquat (Gramoxone), Glyphosate and Dalapon are effective and safe herbicides to be used around the base of seedlings and young palms, for they become inactive in contact with soil. However, care should be taken to prevent spray drift from contacting coconut fronds. In the case of perennial weeds like illuk, couch, foxtail, Cynadon dactylon and Chromolena, use of either Glyphosate or Dalapon is more effective. For control of annual grass weeds like Kuweni and broad-leaved weeds like Euphorbia, application of Paraquat (Gramoxone) at $1-1 \mathrm{~kg} / \mathrm{ha}$ would appear to be effective. In Jamaica, repeated spraying with a mixture of paraquat and diuron (Paracol) at $2.5 \mathrm{l} / \mathrm{ha}$ paraquat and $3 \mathrm{~kg} / \mathrm{ha}$ diuron in a circle of $1.65-240 \mathrm{~m}$ around palms has given effective control against a wide range of grass and broad-leaved weeds and found to be less expensive than manual weeding (Smith 1968 a). 


\section{High density planting}

In dry areas, a possible method of preventing heavy weed infestation druing establishment of new plantations and replantations is to plant seedlings in the triangular systern giving a density of 190 - 200 trees/ ha. This could provide sufficient shade to suppress growth of troublesome weeds like illuk, foxtail, couch and chromolena, for they do not tolerate shady environments.

\section{Grazing}

Sheep rearing to allow repeated grazing on young leaf blade of illuk after slashing aerial parts is another method of controlling this weed. This method can be extended to suppress rank growth of other grasses like Fox-tail and Kuweni and herbaceous weeds like mimosa and mikania. In fact, by controlled grazing of mikania, it can be maintained as a useful cover especially in sandy soils in the dry zone. However, cattle grazing as a tool of biological weed control in young coconut plantation should not be pursued as it can cause considerable damage to seedling.

\section{Intercropping}

For coconut plantations in the Wet and Wet intermediate zones, which offer considerable scope for intercropping, utilisation of space between coconut rows for intercropping with cash and food crops, and improved pasture is another method of suppressing understory weed growth in young plantations. This method is especially suitable for smallholdings and medium size holdings as it would provide some additional benefits including supplementary income. In the case of crops like pineapple, ginger, turmeric, commonly grown in young plantation, it Is a traditional practice to maintain a $10 \mathrm{~cm}$ thick mulch of coir clust to suppress weed growth and retain moisture. Sweet potato, cassava, banana and winged bean are the other crops which act as a 'smother crop' to suppress annul grasses and herbaceous weeds in smallholdings. It has been reported that (San Juan and Abad, 1981) use of winged bean as a ground cover in order to suppress weed growth has improved the soil and given $7 \mathrm{t} / \mathrm{ha}$. of dry matter yield and $89 \mathrm{~kg} / \mathrm{ha}$ of seeds. In the Dry Zone, high density planting in $30 \mathrm{~cm} \times 15 \mathrm{~cm}$ rows of grain legurnes like mungbean, cowpea, groundnut, pigeon pea and gingelly with the onset of rains could effectively suppress the growth of annual grass and herbaceous weeds. Establishment ot improved pastures like Brachiaria miliiformis, B. brizantha, B. ruziziensis and Digitaria decumbens is also possible against annual grass and herbaceous weeds.

\section{Covercropping}

Establishment of legurninous cover crops is an effective method of preventing weed growth in newly established and young plantations. As the initial establishmen of cover is slow, few rounds of light weeding between rows may be necessary to facilitate rapid spread of the cover. In the wet zone, Puero, Calopo and Desmodium ovalifolium could provide very satisfactory control of annual grass and herbaceous weeds. In the Intermediate and Dry Zone, row seeding at $30 \mathrm{~cm} \times 15 \mathrm{~cm}$ spacing of creeping covers like Puero and Centro and bush covers like Tephrosia vogeli (Bogamedilla) and sunhemp Crotolaria juncea could provide effective control against annual grasses and broad-leaved weeds.

Before planting, seeds should be pre-treated by dipping in hot water at $70^{\circ} \mathrm{C}$ for about 3 minutes followed by soaking in cold water for $12-24$ hours. This is essential to enhance seed germination and eliminate growth inhibiting substances on the seed surface. The application of a busal NPK fertilizer mixture at the rate of $1 / 2 \mathrm{~kg}$ urea, $1-2 \mathrm{~kg}$ saphos phosphate and $1 / 2 \mathrm{~kg}$ muriate of potash per coconut square is beneficial especially in sandy soil to allow rapid growth of cover. In dry areas, if initial establishment of cover becomes too difficult, it is advisable to sow seeds on coconut husk or coir clust pits or on coconut husk filled with top soil and bury thern at various points after the emergence of covercrop seedlings, preferably with the onset of rains. Alternately, it is advisable to sow a mixture of Centro/Puero seeds, to minimise the risk of the ground cover being completely 
wiped out during a prolonged dry period. In dry areas, temporary die back of the cover and formation of a mulch of leaf litter is desirable.

To prevent the ground cover from invading the manure circle, it is advisable to maintain 1 - 2 layers of husk mulch around the seedling to a distance of $1.5 \mathrm{~m}$. Further, it is important to suppressexcessive growth of the cover especially in wet areas by running a roller every 6 -months or light harrowing every $1-2$ years.

\section{Weed Management in Mature Plantations}

The management of understory weeds in mature plantation is not so critical, as mature palms could withstand weed competition to some extent. Further, weeds in mature plantations are not so aggressive as in young plantations, which makes it relatively easy to handle understory weed problem. However, one should bear in mind that heavy weed competition, if unchecked for a long period, can cause reduction in nut yield and obstruct estate practices.

Toublesome grass weed like illuk which do not tolerate shade is not dominant in mature plantations exceot in neglected lands. In situations where the understory is invaded by patches of illuk, fox-tail and chromolaena, aerial parts of the weed may be slashed down before flowering occurs. There is a popular saying among planters that 11 one years; seeding means seven years weeding", which emphasises the importance of removing aerial parts before flowering. This should be followed by spraying with 'Roundup' at $2.5 \mathrm{~kg} / \mathrm{ha}, 2-3$ weeks later and establishment of a suitable ground cover.

The traditional practice of burning, to control illuk in mature and neglected plantations should not be continued, for illuk being fire resistant, will only aggravate the problem by rapid regeneration. Further, setting fire particularly in the Dry Zone could lead to 'bush fires' in the plantation causing damage or even death of palms.

\section{Grazing}

Traditionally, cattle raising has been undertaken mainly as tool for weeding. In fact, it has been shown that the use of cattle to control understory weeds in mature coconut plantations is more economical thah manual weeding (Osborne, 1972). For example, the fresh leaf blades that emerge about 2 weeks after slashing of problem weeds like illuk, fox tail grass could be brought under satisfactory control by grazing with buffalo. Other grasses like Kuweni is relished by cattle. It should be noted, however, that continuous grazing or over-grazing by cattle should not be allowed in which animals graze selectively, resulting in the build up of less palatable weeds like Mimosa, Chromolaena, Sida and Cassia species (Gunasekera 1953 a). This is particularly true in low rainfall areas like Puttalam and Kurunegala districts. The herbaceous species like Mikania is another weed which can be grazed by cattlc and maintain as a ground cover in mature plantations. Rearing of sheep is also an effective method of weed control in estates.

\section{Mulching}

If the understory is dominated by annual grass and broad-leaved shrubs and herbaceous weeds, slashing the tall species between coconut rows before flowering and maintaining a mulch of coconut fronds, coconut husks around the palm could be a satisfactory method of control. In the case of legurninous weeds like Pila (Tephrosia purpurea) which thrives well under the shade of mature plantation especially in sandy soil in the Dry Zone and Chromolaena which thrives well in sandy and gravelly soils in the Intermediate and Wet Zone, repeated slashing before flowering during the dry season may be advocated. 


\section{Intercropping}

It is another excellent method of weed management in mature plantations. In the Wet and Wet Intermediate Zone, intercropping with cash crops like Cocoa, Coffee, Pepper, Clove, Banana, Pineapple, Cassava, Sweet-potato, Winged bean (as a cover), ginger and turmeric, and the establishment of rhizomatous or stoloniferous pasture grasses like B. Brizantha, B. milfiformis, $B$. ruziziensisand Digitaria decumbens are known to provide satisfactory control of shrubs and herbaceous weeds that occupy the understory in mature plantations. Studies conducted by the CRI, in the wet and wet intermediate zone have revealed that intercropping with food and cash crops (Lianage 1986) and improved pastures (Santhirasegaram 1966), if done systernatically, will not cause any adverse effects on the yields of coconut. In recent studies, it has been shown that weed growth was reduced by as much as $28-83$ percent in cocoa, coffee, pepper, cinnamon and clove plots when compared with that in coconut monocultures in the wet-zone. This method of suppressing weeds is suitable to both estate and smallholder situations.

\section{Covercropping}

Establishment of legurninous ground cover to suppress understory weed growth in mature plantations is another method especially suitable for estates. The details like suitable species, method of planting and cover management have been already described elsewhere. It will be necessary to slash down the aerial parts of bush covers; like Tephrosia, sunhemp periodically to facilitate nut picking and other estate practices. The loppings from the covers can be used as a green manure around the palms.

Since mature palms can withstand the weed competition, generally weeding may be restricted to periodic slashing, say 6 monthly intervals, of tall weed species (e.g. Lantana camara, Chromolaena, Pila, Ocimum, Cassia species and Sida species) between coconut rows before flowering and maintaining a mulch of coconut fronds without butt ends or 1 - 2 layers of coconut husk around the palm to a distance of $2 \mathrm{~m}$.

\section{Conclusions}

It is evident from foregoing sections that the understory weed cover in coconut plantations consists of a wide range of perennial grasses, shrubs and herbaceous weeds. Although, management of such weeds is an expensive operation, it is being done as a routine practice in order to eliminate or reduce competition between weeds and the palm. Weed competition appears; to be critical during the seedlings; and early growth of palms. Further, weeds are more aggressive and difficult to manage cluring this stage. Therefore, growers should pay more attention to weed management in young plantations than in mature plantations. In the management of troublesome weeds like illuk, foxtail and Chromolaena. and integrated approach is most desirable. In such situations, application of herbicides is more effective and economical in the long run. It should be borne in mind that spot spraying of herbicides against perennial weeds is economical as $10-15$ percent of the total areas is covered. Generally, high concentration of herbicides is necessary to control perennial weeds in young plantations as they are more aggressive and competitive than in mature plantations. Meanwhile, mechanical or cultural methods either alone or in combination provide satisfactory control of annual grass and broad-leaved weeds. Generally, cultural methods using a biological approach are more suitable in smallholdings than herbicidal application. The management rather than eradication of certain weeds like Pila and Mikania for the benefit of the plantation is another point of interest to growers. 


\section{REFERENCES}

Abad, G A and Juan, N C S (1950) Replacement of Cogon (Imperata cylindrica) vegetation under coconut which leguminous covercrops. Annual Report, Philippine Coconut Authority, 75-90.

Gunasekara, G C M (1953a) Pasture under coconut: The incidence of weeds. Ceylon Coconut Quarterly A (1) 9-12.

Juan, N C S and Abad, R G (1981) Preliminary study on the adaptability of winged bean as a cover crop under coconut. Philippine J weed Science, 8, 1-4.

Juan, N C S, Blancaver, R C and Rodriguez, C R (undated). Preliminary study on tolerance of coconut seedlings to different rates of glyphosate. In $12^{\text {th }}$ annual proceedings, Pest Control Council of the Philippines.

Kasasian, L and Seeyave, J (1969) Critical period for wed competition. PANS 15, 108-112.

Liyanage, L V K (1986) Report of the Agronomy Division. Annual Report of the Coconut Research Institute of Sri Lanka: 1986, p 42-43.

Martin, M P L D and Mudaliar, T (1983) Response, of coconut to fertilizer application and weed control. Fiji Agic. J 45 (2) 51-53.

Osborne, H G (1972) Cattle, production and management under coconut. (ed.: E Hugh) South Pacific Commission, New Caledonia, 141-144.

Santhirasegaram, K (1966) The effects of pasture on the yield of coconuts. J. Agric. Soc., Trinidad and Tobago 66, 183-193

Smith, R.W (1968 a) The effects of chernical weed control. on,early growth and onset of bearing in the coconut palm. Technical meeting on herbicides for tree crops with empbasis on coconut. Coconut Industries Board Jamaica. Report of the Research Department P 41-52. 